\title{
Baseline on-site information on coastal recreational fishery and comparison with competitive events in Ilhéus, southern Bahia, Brazil
}

\author{
Kátia Meirelles Felizola Freire ${ }^{1,2,{ }^{*}}$ and Gecely Rodrigues Alves Rocha ${ }^{1}$ \\ ${ }^{1}$ Universidade Estadual de Santa Cruz, Campus Soane Nazaré de Andrade, Rodovia Jorge Amado, km 16 - Salobrinho, Ilhéus - Bahia - Brazil, \\ CEP: 45662-900. ${ }^{2}$ Departamento de Engenharia de Pesca e Aquicultura, Universidade Federal de Sergipe, Cidade Universitária Prof. José \\ Aloísio de Campos, Av. Mal. Rondon s/n, Jardim Rosa Elze, São Cristóvão - Sergipe - Brazil, CEP 49100-000
}

Marine and

Fishery Sciences

MAFIS

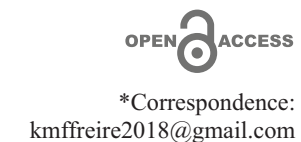

kmffreire2018@gmail.com

Received: 26 October 2020 Accepted: 14 December 2020

ISSN 2683-7595 (print) ISSN 2683-7951 (online)

https://ojs.inidep.edu.ar

Journal of the Instituto Nacional de Investigación y Desarrollo Pesquero (INIDEP)

This work is licensed under a Creative Commons AttributionNonCommercial-ShareAlike 4.0 International License

\begin{abstract}
This study analyzed the profile of recreational fishers on-site in Ilhéus, northeastern Brazil, their fishing habits, and catch composition. Interviews were conducted along the coast of Ilhéus from December 2006 to December 2008 with all fishers encountered and their catch identified and measured. A total of 227 fishers were interviewed in 23 days. Most of the interviewees were men $(93.4 \%)$, residing in Ilhéus $(84.9 \%)$. They preferred fishing in the morning, weekends, and summer. Shrimp was the main bait used. Fishers were generalists, but most of the catch included Polydactylus virginicus, Ariidae, and Menticirrhus littoralis. Catches observed during the interviews allowed to estimate an annual catch of $1.4 \mathrm{t}$. A proportion of $88 \%$ of fishers practiced catchand-release, mainly small fishes. Only $10 \%$ of them carried license for recreational fishing and about $5.3 \%$ were members of fishing clubs. This provides a unique opportunity to compare our results with those from another study conducted in the same locality during the same period with members of fishing clubs. These fishers used very small hooks during competitive events, which resulted in the capture of smaller fishes than was reported here on-site. This study sets a baseline to analyze temporal changes in fishing habits and catch.
\end{abstract}

Key words: Sport fishery, recreational fishing, coastal fishery, catch composition, demographic profile, northeastern Brazil.

Información de base in situ sobre la pesca recreativa costera y comparación con eventos competitivos en Ilhéus, sur de Bahía, Brasil

RESUMEN. Este estudio analizó el perfil de los pescadores recreativos in situ en Ilhéus, noreste de Brasil, sus hábitos de pesca y la composición de las capturas. Se realizaron entrevistas a lo largo de la costa de Ilhéus desde diciembre de 2006 a diciembre de 2008 con todos los pescadores encontrados y su captura fue identificada y medida. Se entrevistó a un total de 227 pescadores en 23 días. La mayoría de los entrevistados eran hombres $(93,4 \%)$, residentes en Ilhéus (84,9\%). Preferían pescar por la mañana, los fines de semana y el verano. El camarón fue el cebo principal utilizado. Los pescadores eran generalistas, pero la mayor parte de la captura incluía Polydactylus virginicus, Ariidae y Menticirrhus littoralis. Las capturas observadas durante las entrevistas permitieron estimar una captura anual de 1,4 t. Una proporción del 88\% de los pescadores practicó la captura y liberación, principalmente de peces pequeños. Solo el 10\% de ellos tenía licencia para la pesca recreativa y alrededor del 5,3\% eran miembros de clubes de pesca. Esto brinda una oportunidad única para comparar nuestros resultados con los de otro estudio realizado en la misma localidad durante el mismo período con miembros de clubes de pesca. Estos pescadores utilizaron anzuelos muy pequeños durante los eventos competitivos, lo que resultó en la captura de peces más pequeños de lo que se informó aquí in situ. Este estudio establece una línea de base para analizar los cambios temporales en los hábitos de pesca y la captura. 
Palabras clave: Pesca deportiva, pesca recreacional, pesca costera, composición de la captura, perfil demográfico, noreste de Brasil.

\section{INTRODUCTION}

Recreational fishery is defined as "fishing of aquatic animals (mainly fish) that do not constitute the individual's primary resource to meet basic nutritional needs and are not generally sold or otherwise traded on export, domestic or black markets' (FAO 2012). This definition is also valid for Brazil, except that recreational catch selling is not allowed in any circumstance (MPA/MMA 2012). Catches originating from recreational fisheries should be added to those commercial fisheries to better access the status of main stocks throughout their distribution areas. A recent initiative, using all possible data sources available from recreational fisheries estimated that around 0.9 million tonns were extracted from marine waters around the globe in 2014 (Freire et al. 2020). This estimate may be low when compared to those from commercial fisheries, which accounted for 93.4 million tonns in the same year (FAO 2016), but it is always important to point out that recreational catches might surpass commercial catches for some resources in certain areas (Coleman et al. 2004).

The main challenge in compiling catch data from recreational fisheries is its geographically disperse nature, with recreational fishers looking for remote areas to get better fishing experiences. Many recent initiatives have been trying to recover past information on catches using the most diverse types of data (see, e.g., Espedido et al. 2014; Belhabib et al. 2016; Babali et al. 2018). Competitive fishing events are particularly important to provide at least some initial information for certain places on who is fishing, what is fished, how are they fishing and how large are their catches, as these events represent a concentration of fishers and data (Schramm Jr. and Har- rison 2008; Freire et al. 2016). However, catches originating from competitive fishing events represent only a partial picture. Moreover, fishers' behavior during these events and outside the events may differ.

Freire et al. (2020) analyzed the profile of recreational fishers in Ilhéus (2006-2008), in southern Bahia, as well as their fishing habits, using information collected during competitive fishing events. This area is particularly important as it lodges the second oldest fishing club in Bahia, Clube de Pesca de Ilhéus (CLUPESIL), founded in 1975 (Freire 2010), which is very active in promoting competitive events. The present paper aimed at describing the profile of recreational fishers in Ilhéus fishing outside competitive fishing events (hereafter called on-site) during the same period (2006-2008), and at comparing the fishing habits and catch composition onsite with those of competitive events. Data analyzed here do not provide information on the status of local recreational coastal fisheries, but provide a valuable source of baseline information that can be used to compare with more current data to assess possible changes after 12 years.

\section{MATERIALS AND METHODS}

During this study, the northern, central, and southern coast of Ilhéus were visited alternatively once a month from December 2006 to December 2008 (Figure 1). Central beaches are located in a very urbanized area separated from the northern beaches by the estuary of Almada River and from the southern beaches by the estuary of Cachoeira River. Visits started at the beginning of the day (the earliest was at 8:47 am) and would not end until the last kilometer of beach was visited (the latest was at 5:47 pm). No attempt was done to 


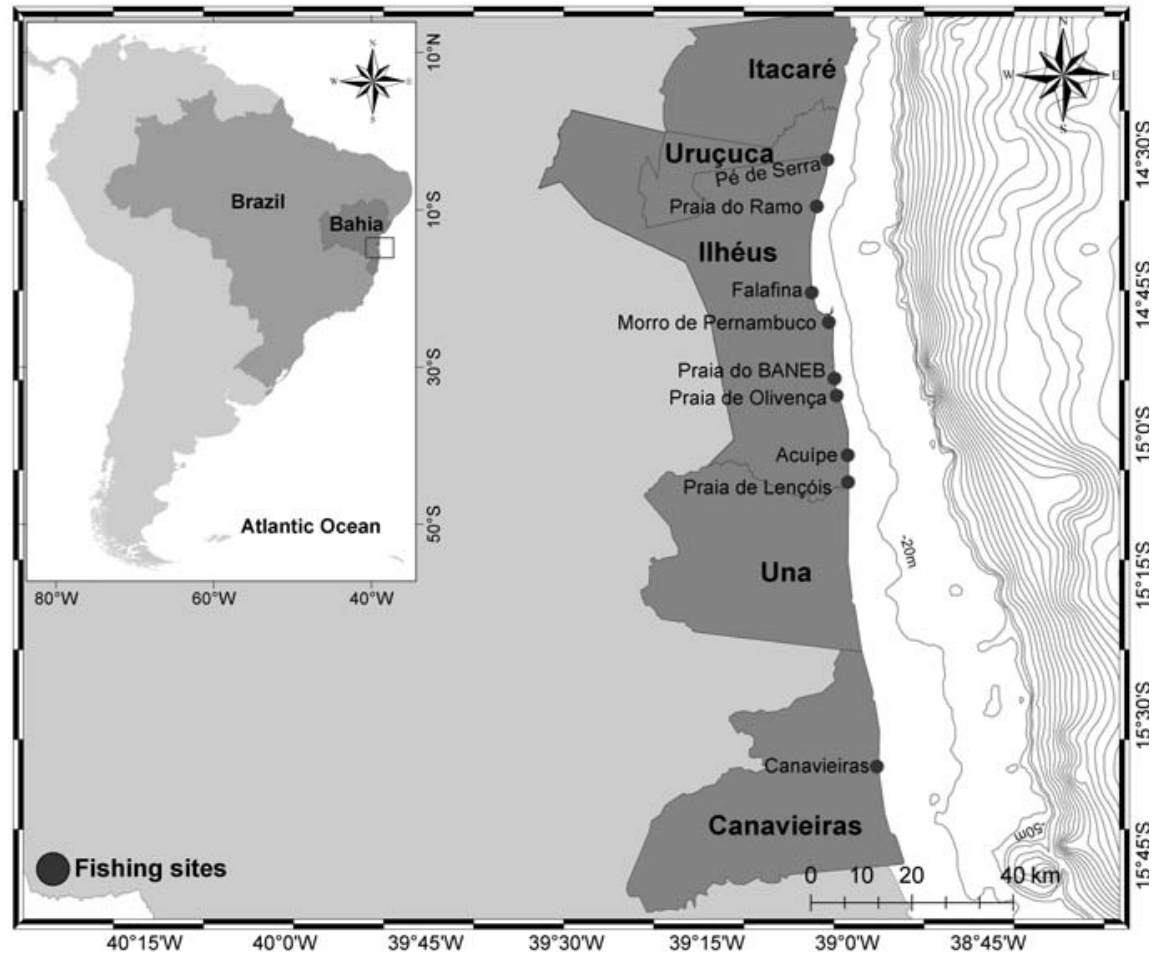

Figure 1. Map showing Ilhéus and the main fishing sites located between Itacaré and Canavieiras, in southern Bahia.

cover nocturnal fishing activities due to the remoteness of fishing areas and safety issues. Survey days were not randomly chosen due to logistic reasons, but there were interviews in all days of the week, except for Tuesdays. Every time one or a group of recreational fishers was spotted at the beach (on-site), using binoculars, our team interviewed all of them making use of a questionnaire with closed- and open-ended questions to obtain demographic data and information on fishing habits. Moreover, we identified and measured all fishes caught on-site. Demographic questions included age, sex, occupation, and place of residence. In terms of fishing habits, questions were related to participation in fishing clubs, acquisition (or not) of recreational fishing license, target species, type and number of fishing gears used, bait, and hook size. For the hook size, we used a model where all sizes available in the market for coastal recreational fishers were glued onto a metallic plate to avoid problems with the size definition among different hook brands. Preferred time of the day, day of the week, and month to go fishing were also included, as well as the preferred fishing site. Catch-and-release habits and the destination of those specimens retained (consumption, donation, or sale) were also questioned. Finally, fishers were asked to relate the main problems observed with recreational fisheries in the region.

Additionally, fishers were asked about the number of fishes caught by species' common name up to the moment of the interview and if the individuals were released or not. If not, all specimens were measured on-site (total length - TL, $\mathrm{cm}$ ) or weighed (total weight - TW, g) and these measurements were converted into each other using weight-length relationships (WLRs) available in FishBase (Froese and Pauly 2019) for the same (or the closest possible) region. The catch 
observed during the 23 days of interviews was used to estimate a daily catch, which was then utilized to calculate catch for one year using a simple extrapolation: daily catch (total observed catch/number of survey days) $\times 365$ days. No attempt was done to consider differences among fishing sites (northern, central, or southern beaches) or different days of the week, due to the reduced sampling effort.

\section{RESULTS}

Our team conducted 264 interviews in 23 different days with 227 recreational fishers. These interviews were almost equally divided between weekdays and weekends (Table 1). Results presented from demographic questions and fishing habits are related only to these 227 fishers, but catch rates are related to all 264 interviews. Most of the interviewees were men (93.4\%). Some of them were interviewed more than once $(1,2,3$ or 6 times). Only $10 \%$ of the fishers carried a recreational fishing license and about 5.3\% were members of fishing clubs. A proportion of $84.9 \%$ of the interviewed fishers were residents of Ilhéus (in the state of Bahia) and $97.5 \%$ residents of
Bahia (including Belmonte, Itabuna, Itapetinga, Jacobina, Porto Seguro, and Salvador, besides Ilhéus). The remaining fishers lived in Brasília (capital of Brazil), Minas Gerais, Rio de Janeiro, and Pernambuco. In terms of occupation, interviewees were either retired $(16 \%)$, vendors $(12 \%)$, security officers $(7 \%)$, public servants $(5 \%)$, students $(5 \%)$, or construction workers $(4 \%)$. The sector is highly diverse with another 44 occupations reported.

Recreational fishers in Ilhéus usually do not have specific target species (92\%). Carangids (jack, pompano, and Atlantic pumper), barbu, and snook were the mostly cited among those who have targets. An extremely low number of fishers (one or two fishers) target ray, mojarra, shark, catfish, and weakfish. The most common fishing gear used was reel ( $90 \%$ of all fishers), followed by handline, pole and line, and spear (Table 2). Those using reels kept one ( $71 \%$ of fishers), two (24\%), or three $(5 \%)$ lines in the water at the same time. Recreational fishers use a variety of hook sizes, from exceptionally large, including those used by commercial fishers $(>3 / 0)$, to exceptionally small (24, called unha de gato) (Figure 2). Many fishers chose hook sizes in between standard sizes provided as samples in a showcase metallic plate. A proportion of $62 \%$ of the recreational fishers inter-

Table 1. Number of interview days $(\mathrm{N})$ conducted on-site by day of the week with recreational fishers in Ilhéus, southern Bahia, from December 2006 to December 2008 and the minimum, mean and maximum number of fishers interviewed.

\begin{tabular}{lcccc}
\hline Day of week & N & Minimum & Mean & Maximum \\
\hline Monday & 2 & 4 & 8 & 11 \\
Tuesday & 0 & - & - & - \\
Wednesday & 1 & 18 & 18 & 18 \\
Thursday & 8 & 1 & 10 & 20 \\
Friday & 1 & 1 & 15 & 1 \\
Saturday & 7 & 5 & 12 & 24 \\
Sunday & 4 & 2 & 12 & 24 \\
\hline Total & 23 & 1 & & \\
\hline
\end{tabular}


viewed on-site stated that they use size 5 hooks or larger and 38\% said they use smaller than size 5 . These results differed from the statements presented by recreational fishers interviewed by Freire et al. (2020) in Ilhéus during competitive fishing events taking place in the same period. A propor-

Table 2. Gear types used by recreational fishers in Ilhéus, southern Bahia, interviewed between 2006 and 2008.

\begin{tabular}{lc}
\hline Gear & Proportion (\%) \\
\hline Spinning reel (molinete) & 80.4 \\
Reel (carretilha) & 9.8 \\
Handline & 5.3 \\
Mixed & 2.2 \\
Pole and line & 1.8 \\
Spear & 0.4 \\
\hline
\end{tabular}

tion of $50 \%$ of those fishers stated the use of size 5 hooks or larger when fishing outside competitive events and 50\% used hooks smaller than size 5 (Figure 2). Finally, those same fishers used smaller hook sizes during competitive events, which is reflected in a reverse proportion $(5 \%$ for size 5 hooks and larger, and 95\% for hooks smaller than size 5; Figure 2). Crustaceans (87.9\%), fishes $(10 \%)$, and mollusks $(1.7 \%)$ were used as bait by the interviewed fishers (Table 3 ). One fisher mentioned the use of beef as bait. Among the crustaceans, shrimps were the most common (77.8\%), followed by ghost shrimps (7.5\%). All the remaining types contributed less than $5 \%$.

When asked to state the preferred time of the day to go fishing, $67 \%$ of the fishers mentioned the actual hour of the day and 33\% said it depends on the tide. Those who stated by time, preferred going fishing during the morning (6 am to noon;

A

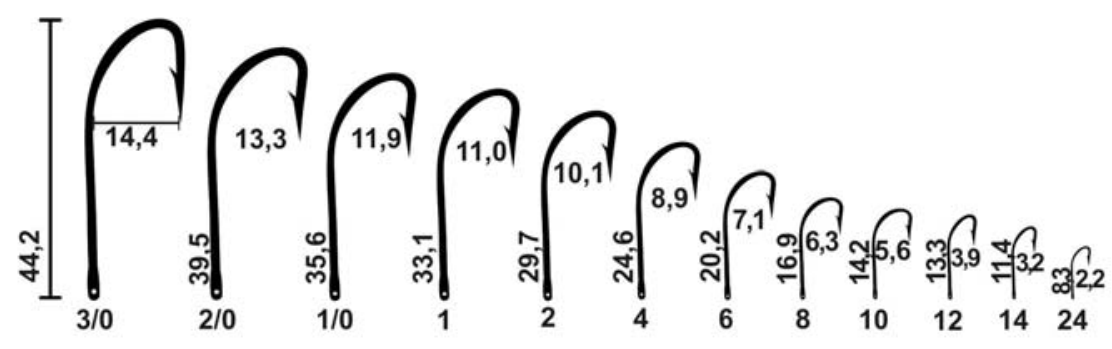

B

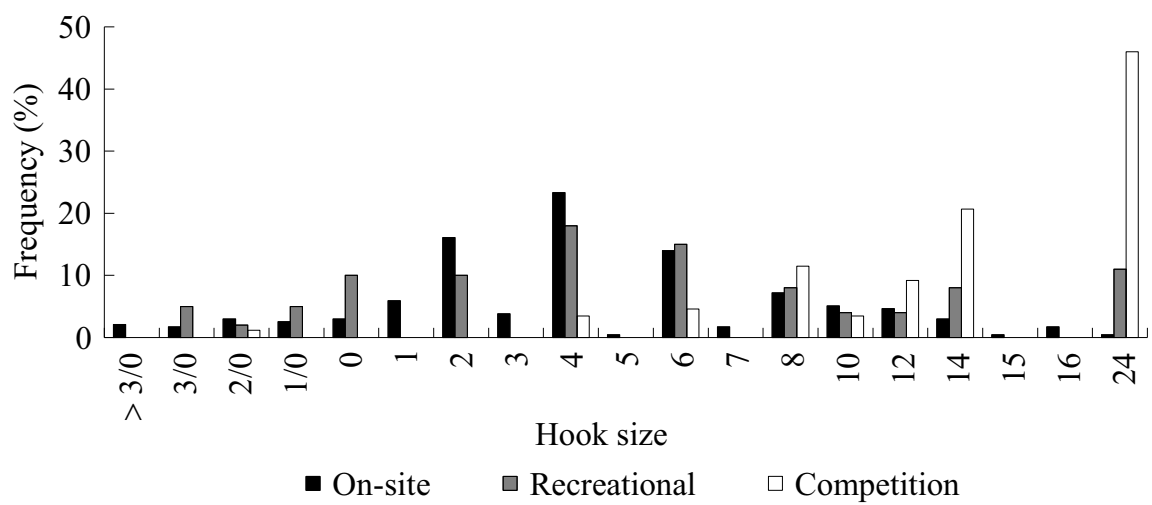

Figure 2. Standard hook size $(\mathrm{mm})$ provided as samples in a showcase metallic plate used during on-site interviews with recreational fishers in Ilhéus, southern Bahia, in 2006-2008 (A); hook size that these on-site fishers stated using in their daily activities (black columns) (B). For comparison purposes, hook size that fishers interviewed in competitive events mentioned using during their daily recreational activities (grey column) and in competitive events were included (modified from Freire et al. 2020). 
Table 3. Bait types mentioned by recreational fishers interviewed on-site in Ilhéus from December 2006 to December $2008 . \mathrm{N}$ = number of times each bait type was mentioned (each fisher could list up to three types) and $\mathrm{P}=$ proportion $(\%)$. Bold numbers $=$ sum of frequencies for each large group.

\begin{tabular}{lccc}
\hline $\begin{array}{l}\text { Portuguese } \\
\text { common name }\end{array}$ & $\begin{array}{c}\text { English } \\
\text { common name }\end{array}$ & Taxon & N \\
\hline
\end{tabular}

\section{Crustaceans}

Camarão

Camarão branco, branco de rio, branco do mangue

Camarão rosa, camarão rosinha

Camarão sete barbas

Corrupto

Siri mole

Tatuí, tatuzinho

Fishes

Peixe, peixe pequeno, peixe vivo

Sardinha

Manjuba

Cascudo

Tainha

Barbudo

Carapicu

\section{Mollusks}

Lula

Polvo

Octopus

Sardine

Anchovy

False herring

Mullet

Threadfin

Mojarra

Atlantic seabob

rimp

ing crab

Penaeidae Rafinesque, 1815

Litopenaeus schmitti (Burkenroad, 1936)

160

87.9

White shrimp

16

66.9

16

6.7

Farfantepenaeus spp. Burukovsky, 1997

Xiphopenaeus kroyeri (Heller, 1862)

Callianassidae Dana, 1852

Portunidae Rafinesque, 1815

Hippidae Latreille, 1825

$\begin{array}{rr}5 & 2.1 \\ 18 & 7.5 \\ 4 & 1.7 \\ 2 & 0.8\end{array}$

10.0

Actinopterygii

10

Clupeidae Cuvier, 1816

1.7

Engraulidae Gill, 1861

Harengula clupeola (Cuvier, 1829)

Mugil spp. Linnaeus, 1758

Polydactylus sp. Lacepède, 1803

Eucinostomus sp. Baird and Girard, 1855

4

1.3

1.3

3

0.8

$1 \quad 0.4$

$1 \quad 0.4$

Myopsida

Octopoda Leach, 1818

Others

Carne

Beef

-

Figure 3 A). Preference decreases in the afternoon and even further at night (Figure $3 \mathrm{~A}$ ). Those who stated by tide, preferred going fishing mainly during flushing and breaking tides (Figure 3 B). Fishers would preferentially fish during week- ends, despite the occurrence of fishing activities throughout the week (Figure 4 A). Even though fishers stated they could go fishing all year round, there was a preference for the summer (December until February; Figure 4 B). In general, most 

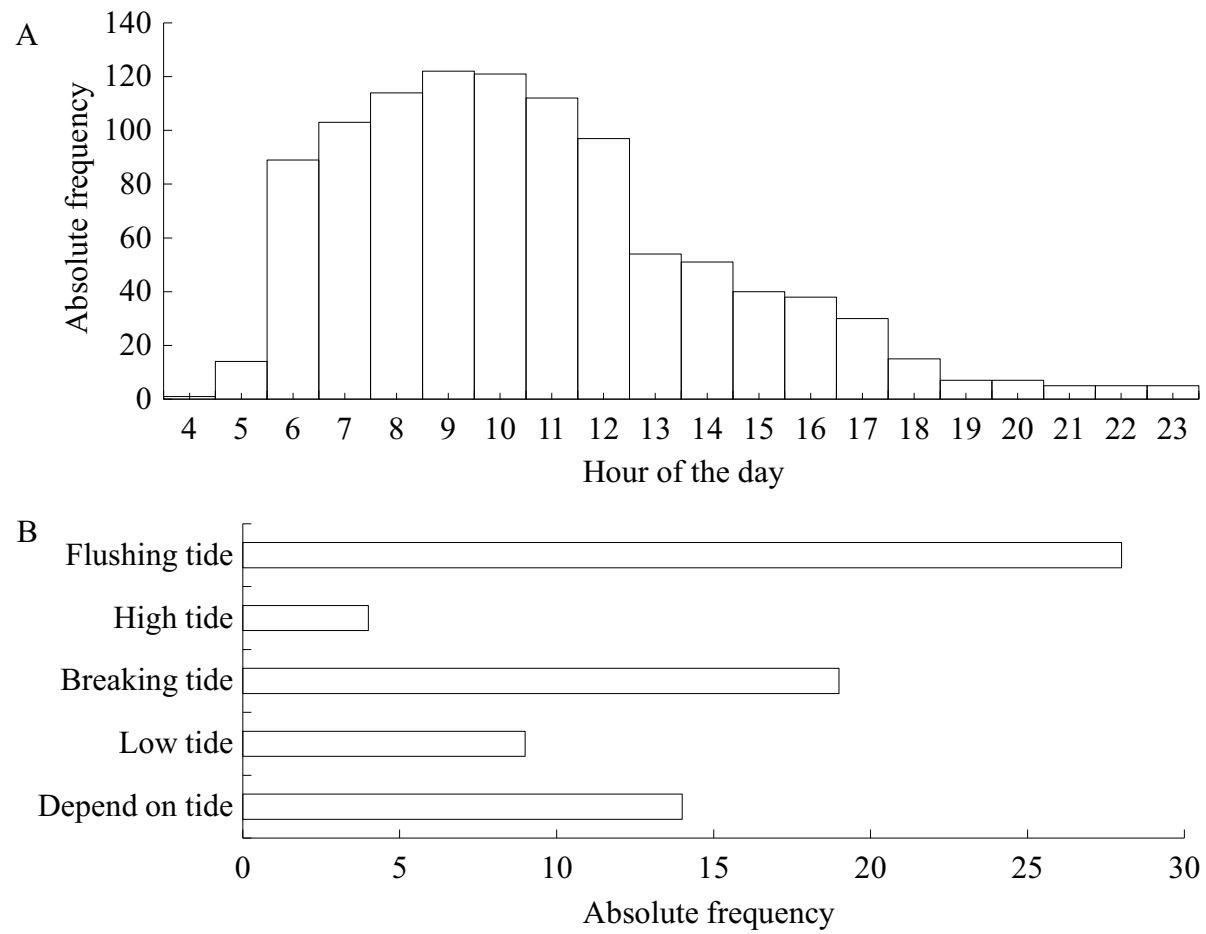

Figure 3. Preferred time of the day to go fishing stated by recreational fishers on-site in Ilhéus, southern Bahia, in $2006-2008$. A) By hour. B) By tide.

A

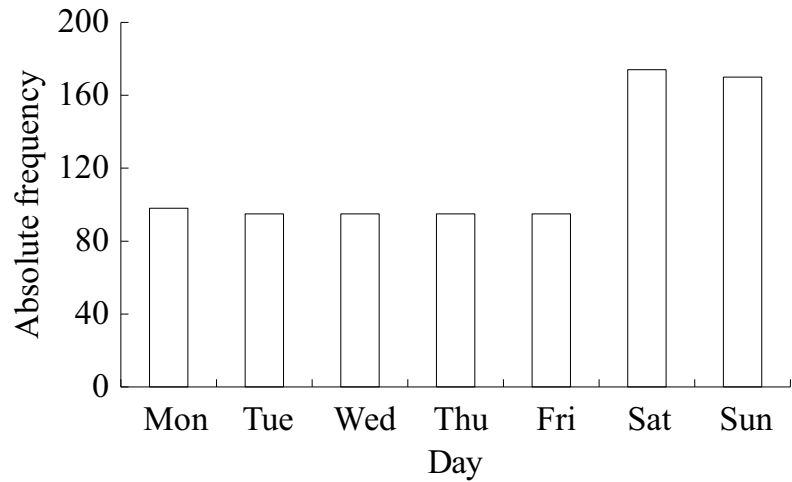

B

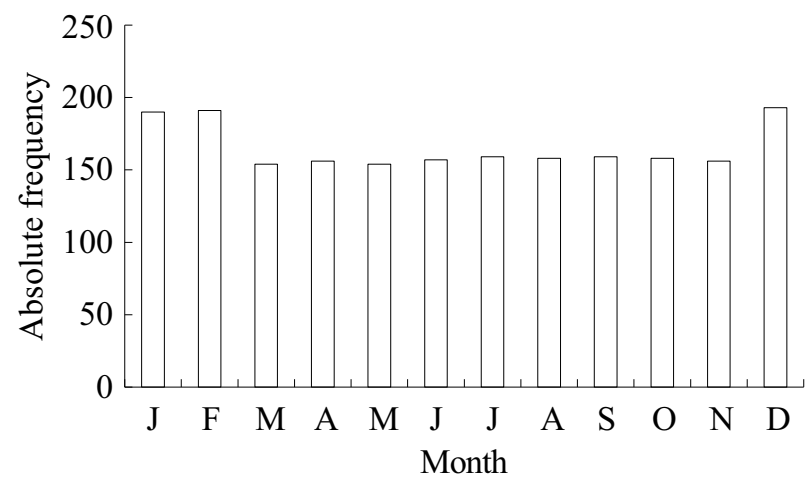

Figure 4. Days of week (A) (Monday to Sunday) and months of the year (B) (January to February) that recreational fishers stated they prefer to go fishing in Ilhéus, southern Bahia, in 2006-2008.

fishers preferred going fishing in southern beaches - SB (57\%), followed by northern beaches NB (25\%), and central beaches - CB (18\%) (Figure 5). More particularly, the following localities were the most cited: Morro de Pernambuco (CB),
Falafina (NB), Lençóis (SB), and Acuípe (SB) (Figure 5). Two fishers preferred fishing offshore and one in rivers, and eleven of them had no preference. A total of $85 \%$ of all fishers consume their catch, $22 \%$ donate, and $1 \%$ sell it. About $2 \%$ of 


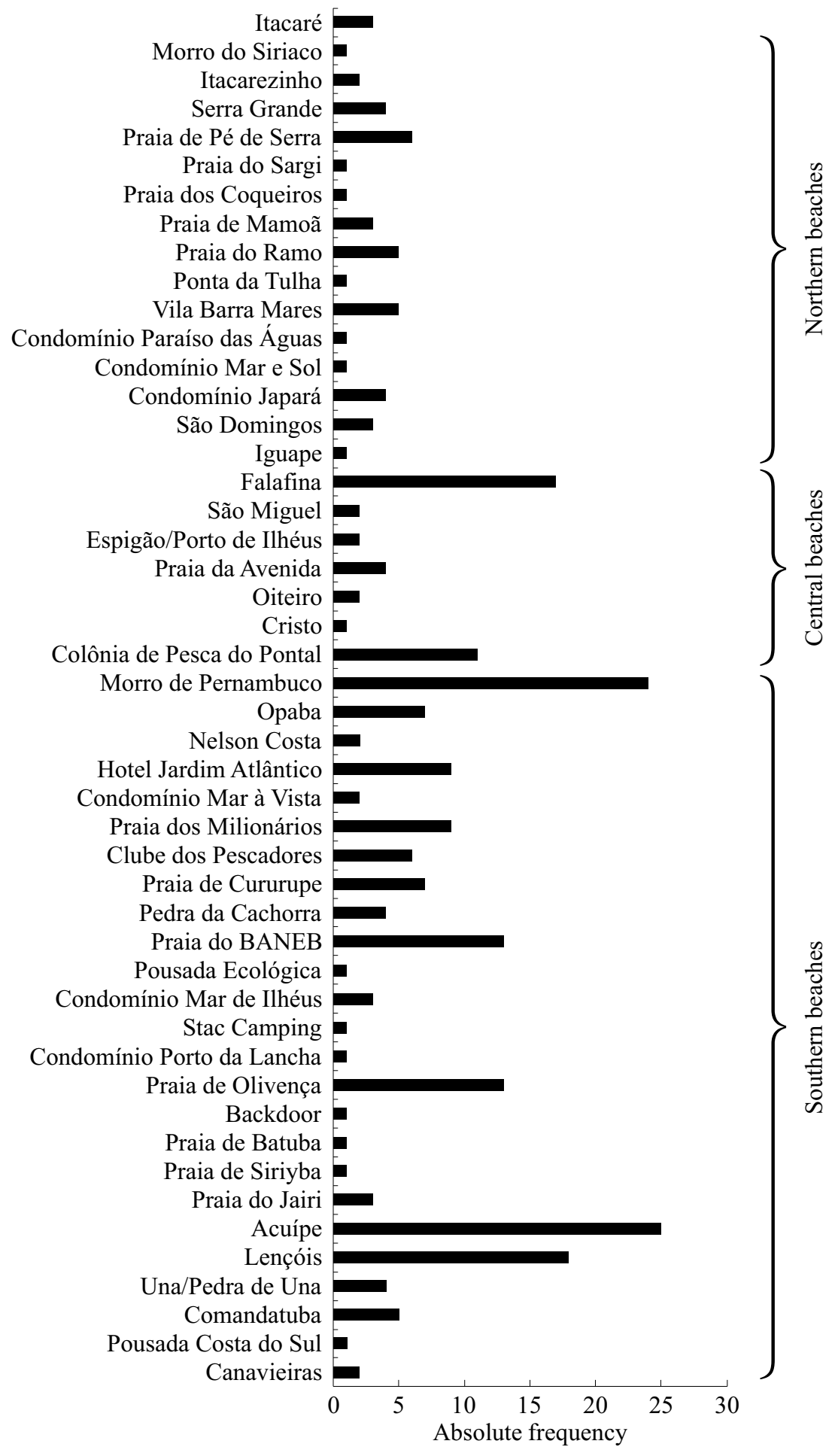

Figure 5. Preferred fishing sites stated by recreational fisheries interviewed on-site in Ilhéus, southern Bahia, in 2006-2008. 
them never caught a fish. Finally, $88 \%$ of the fishers interviewed released fishes in the following cases: small size $(71 \%)$, catfish $(7 \%)$, pufferfish $(3 \%)$, spawners $(1 \%)$, and others $(4 \%$; including small catfish, ray, snook during the spawning period, large snapper, mullet, mackerel, bonefish, and turtle). Some fishers released fishes in more than one of these cases.

Main problems mentioned by recreational fishers interviewed on-site were shrimp and 'calão' fisheries (shore-based trawl fishery), which lead to decreasing abundance of fishes (Figure 6). The decreasing abundance was also associated to pollution in its diverse forms (on the beach sand, sewage, rivers, etc.) and to predatory fishery in general (no mention about type of predatory fishery). All remaining problems were cited by five or less fishers. It is worth mentioning that global warming was pointed out as one of the problems, as well as decreasing water temperature caused by changes in circulation. These last changes may be associated to the port construction and placement of groins close to the port area, which were both mentioned as problems as well (Figure 6).

A total of 367 fishes were caught by recreational fishers during this study, corresponding to $87.5 \mathrm{~kg}$. This led to an estimated mean annual catch by shore-based recreational fishers of $1.4 \mathrm{t}$ (estimated on-site). This could be considered an underestimate as it does not consider fishes caught by the same fishers after our interview or by those fishers who may have arrived after our interview was conducted. A total of 23 taxa were reported during the interviews, with the most abundant being Polydactylus virginicus (Linnaeus, 1758), Ariidae Bleeker, 1858, Menticirrhus littoralis (Holbrook, 1847), Trachinotus goodei Jordan and Evermann, 1896, Trachinotus spp. Lacepède, 1801, and Eucinostomus spp. Baird and Girard, 1855 (Table 4). Some of the individuals could not be identified at species level as they were returned to the sea or due to lack of laboratory infrastructure on-site. A proportion of $87 \%$ of all $P$. virginicus measured were below the maturity size of $22.1 \mathrm{~cm}$ estimated by Freire et al. (2020). Similar proportion of M. littoralis $(85 \%)$

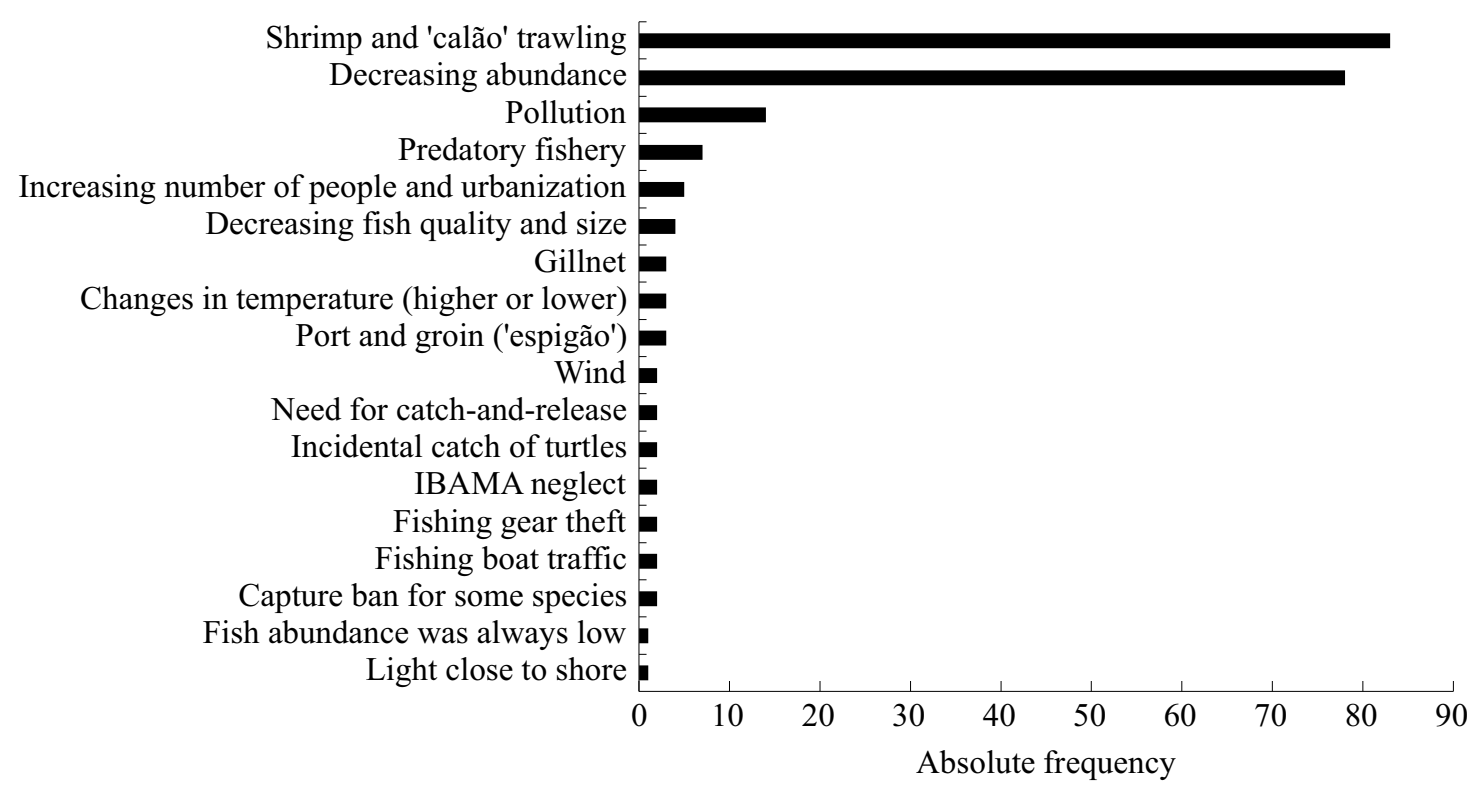

Figure 6. Problems that local recreational fisheries have been facing during the last years according to recreational fishers interviewed on-site in Ilhéus, southern Bahia, in 2006-2008. IBAMA = Brazilian Institute for the Environment and Renewable Natural Resources. 


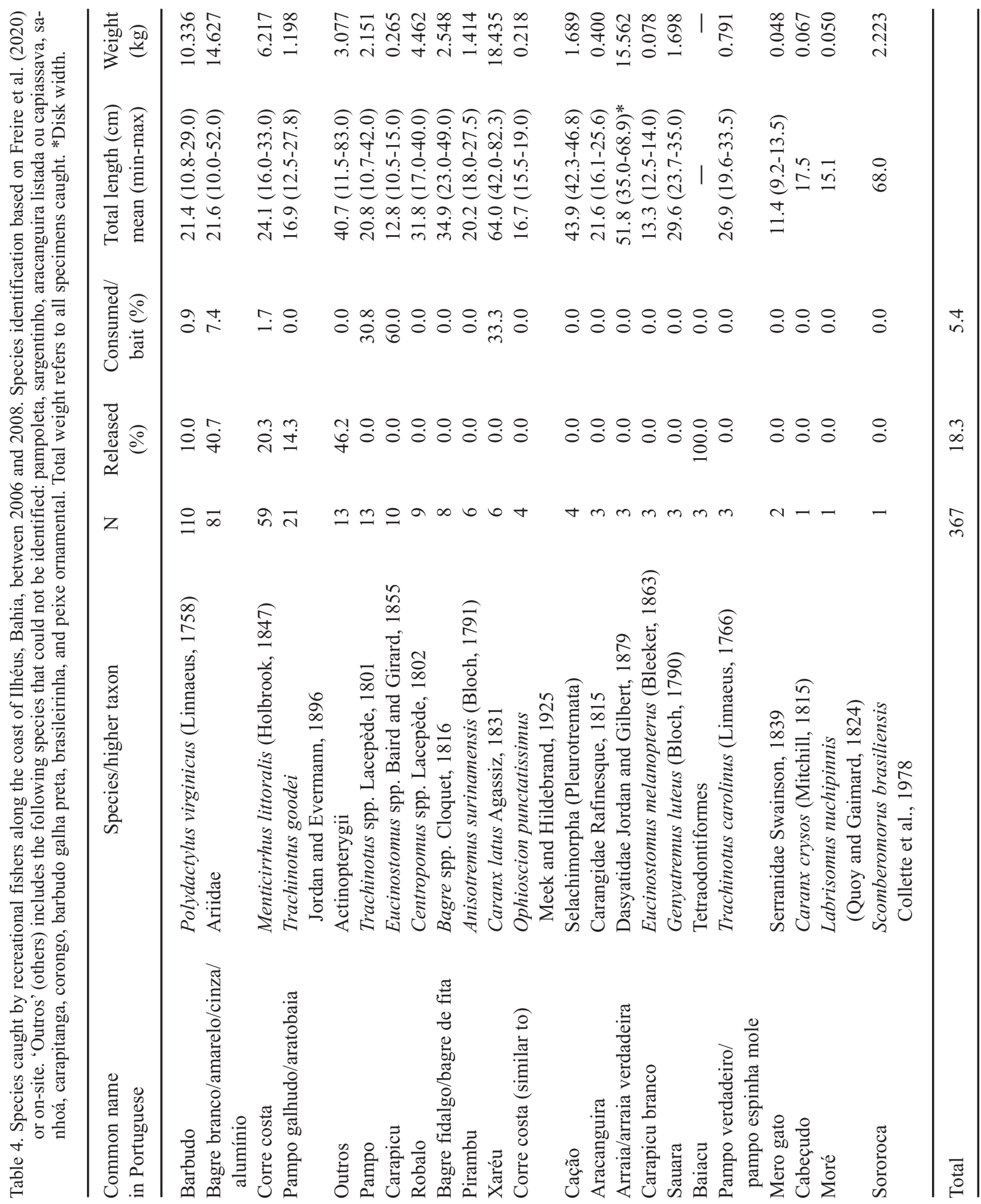


was also below the maturity size of $23 \mathrm{~cm}$ estimated by Braun and Fontoura (2004). No information published on maturity size was found for T. goodei.

About $18.3 \%$ of the 367 fishes registered were released and $5.4 \%$ were consumed on-site or were used as bait. Ten to forty per cent of the four most abundant taxa were released and $30-60 \%$ of the last two taxa were consumed or used as bait (Table 4). All pufferfishes were released. Total length of fishes ranged from 9.2 (Serranidae Swainson, 1839) to $83.0 \mathrm{~cm}$ (unidentified 'corongo', Actinopterygii), with a mean length of 23.5 cm TL.

\section{DISCUSSION}

A total of $5.3 \%$ of the interviewees were members of fishing clubs, thus a different group was reached in this study than in that carried out by Freire et al. (2020) in the same period. This is a unique opportunity to check for differences and/or communalities between these two studies. Many features are similar, including mean age, predominance of men, fishing habits (main bait used, preferred time and day of the week for fishing), and problem perception (Table 5). However, there is one main difference that leads to important divergences: the proportion of fishers without a fishing license was remarkably high (90\%) in this study, which contrasts with the $0 \%$ of those interviewed during competitive fishing events in Ilhéus (Table 5). This happens because these events, promoted by the Clube de Pesca de Ilhéus (CLUPESIL), are officially recognized by the Brazilian Confederation of Fishing and Underwater Sports (CBPDS), and this Confederation requires that each participant presents his/her national recreational fishing license. Some important implications arise from such a low proportion of fishers on-site carrying a fishing license, as it makes evident that the licensing system currently in place in Brazil does not include many recreational fishers. Thus, any fishing estimates using information obtained merely from questionnaires filled when acquiring this license may be biased despite attempts to correct for the actual number of fishers (see, e.g., Freire and Sumaila 2019).

Additionally, fishers interviewed during competitive events (Freire et al. 2020) stated they used medium sized hooks outside competitive events, similar to those interviewed on-site, but very small hooks during competitive events. This occurs because the pointing system adopted in these events favors the number of specimens caught over individual weight (Freire et al. 2020). Indeed, the maximum weight of fishes caught in competitive events $(670 \mathrm{~g})$ was smaller than the mean weight observed on-site (735 g; maximum $=10,000 \mathrm{~g})$, where fishers used exceptionally large hooks (even larger than the samples presented which correspond to those used by commercial fishers).

In competitive events that took place in Ilhéus in 2007-2008, Cathorops spixii (Agassiz, 1829) catches were more abundant (Freire et al. 2020). In our study conducted on-site in the same municipality and in the same period, ariids ranked second in number but it was not possible to identify all species caught within this group. Even though C. spixii is commonly cited in ichthyofaunal surveys along the Brazilian coast and commercialized in some areas (Fávaro et al. 2005), ariids in general were not appreciated by local recreational fishers for consumption (personal observation), with about $41 \%$ of them being releasing. Catfishes are seen as food taboo together with other scaleless fishes (Hanazaki and Begossi 2006). Even though reasons for releasing were not specifically included in the interview, it may be related to the detritivore diet associated to its benthic habitat (Hanazaki and Begossi 2006), as stated by some fishers during the interview. On the other hand, $P$. virginicus was ranked first on-site, being highly appreciated for consumption and hence only $10 \%$ of them were released. Ariids 
Table 5. Comparison between features of recreational fisheries according to fishers interviewed on-site (this study) and in competitive fishing events (modified from Freire et al. 2020) in Ilhéus, southern Bahia (2006-2008). *Value to the left corresponds to hook size used during competitive events and the one to the right when fishing outside competitive events. **Percentage of fishers who stated the practice of catch-and-release, which differs from the proportion of fishes released during our interviews (18.3\%; Table 4).

\begin{tabular}{lll}
\hline Feature & \multicolumn{1}{c}{ On-site } & Competitive events \\
\hline Men (\%) & 93.4 & 75.0 \\
Mean age (min-max) & $43.7(10-79)$ & 41.1 (7-70) \\
Member of fishing clubs (\%) & 5.3 & 100 \\
Fishing license (\%) & 10 & 100 \\
Most cited hook size & 4 (medium) & 24 (small)/4 (medium)* \\
Main bait & Shrimp & Shrimp \\
Catch-and-release (\%) & $88^{* *}$ & 98 \\
Preferred fishing hour & Morning & Morning \\
Preferred fishing day & Weekend & Weekend \\
Preferred fishing month & Summer (Dec-Feb) & None \\
Preferred fishing site & Morro de Pernambuco, Acuípe & Acuípe \\
Main problem & Shrimp/'calão’ trawling & Shrimp/'calão' trawling \\
Main species caught (\% in number) & Polydactylus virginicus (30) & Cathorops spixii (33) \\
Fish mean size (min-max; cm) & 23.5 (9.2-83.0) & 11.8 (4.6-57.5) \\
Fish mean weight (min-max; g) & $735.0(11.0-10,000.0)$ & 28.7 (0.9-670.0) \\
\hline Number of interviewees & 227 & 57 \\
\hline
\end{tabular}

and $P$. virginicus were also among the dominant catches by coastal recreational fishers in Sergipe (Freire et al. 2017) together with M. littoralis. To the best of our knowledge, there is no information published for other states in northeastern Brazil on coastal recreational fisheries other than the ones cited here for Sergipe and Bahia.

A high proportion of $M$. littoralis (about 20\%) was released by fishers interviewed in Ilhéus in this study. Considering that $P$. virginicus and $M$. littoralis are appreciated for consumption, they were probably released due to small size. Even though these species are listed among the most abundant in the catches sampled on-site, fishers are generalists as $92 \%$ had no target species. A total of 22 taxa were reported in this study (among species, family, and order) and one cate- gory named 'others' (including nine species reported by common name but not properly identified). Only five of these species/group of species were also reported for commercial fisheries (CEPENE, 2007): 'arraia' (ray), 'bagre' (catfish), 'cação' (shark), 'robalo' (snook), and 'xaréu' (jack). This indicates an extra pressure on these same resources. The fact that 15 other species caught by recreational fishers were not individually reported in catch statistics of commercial fisheries does not imply lack of overlapping. Instead, these species may be recorded along with others under the category 'outros' (others), revealing difficulties raised by the richness of names in catch statistics again (Freire and Pauly, 2005). Studies on coastal recreational fisheries are still rare in Brazil, but in some of them 
the same pattern was observed. In Santos (state of São Paulo), in an inner region of the coast (Deck do pescador), fifteen species were cited as target by local recreational fishers, including Menticirrhus americanus (Linnaeus, 1758) and C. spixii (Barrella et al. 2016). About $50 \mathrm{~km}$ to the south, in the Plataforma Marítima de Pesca Amadora de Mongaguá (state of São Paulo), about 55\% of all specimens caught were ariids, even though Trichiurus lepturus was the main target (Alves Junior et al. 2020). In sand beaches in southern Paraná, Menticirrhus and ariids were the most cited target by local recreational fishers, together with at least eight other species (Henke and Chaves 2017). In Cidreira (northern Rio Grande do Sul), a large number of species was caught, despite the dominance of sciaenids (Lewis et al. 1999). In Cassino Beach (southern Rio Grande do Sul), differently from all these studies cited above, recreational fishers are specialists targeting and catching mainly Menticirrhus spp. (Basaglia and Vieira 2005). Even though a high variety of species is caught by coastal recreational fishers in Brazil, catches are usually dominated by Menticirrhus and catfishes.

This study represents a further step towards describing the coastal recreational fishery in Ilhéus, providing historical information on the demographics of its recreational fishers, their fishing habits, and their catch rates. Considering that recreational fisheries is a new research field in Brazil, there are very few baseline studies available in the country and the information provided here using data from 12 years ago could be used to observe any changes. Thus, we noticed that, at that time, on-site generalist recreational fishers extracted around $1.4 \mathrm{t}$ annually in Ilhéus. Even though this estimate was low in relation to commercial fisheries for the same period (about $110 \mathrm{t}$ in 2005; CEPENE, 2007), it represents only a partial portrait as nocturnal fisheries were excluded from this analysis - no interview was conducted between $6 \mathrm{pm}$ and 6 am despite declarations of some fishers about fishing during this period (Figure 3). Similarly, catches from competitive events, offshore activities, or spearfishing were not included. Innovative ways of compiling more complete information are required to better describe recreational fisheries in Ilhéus and Brazil as a whole in the near future. Despite the increasing number of studies on recreational fisheries along the Brazilian coast, we are far from properly covering even the most basic issues at the national level, such as number of recreational fisheries along the entire coast, main species caught, and total catch.

Based on what was presented here, the first question of the section entitled 'resource monitoring and data acquisition', out of the 100 research questions raised by Holder et al. (2020), 'how do we promote angler engagement in the provision of reliable and accurate catch and effort information?', is valid for Brazil if we are to produce catch statistics reflecting total extraction from Brazilian marine waters. Modern tools are available to collect such information in a wider scale and should be better explored and utilized here. If we wait for local studies to be conducted along the entire coast by a reduced number of researchers working on recreational fisheries to be able to accurately describe these Brazilian recreational fisheries, it will take a long time to cover the entire coast and all fishery types. Hence, we should start thinking about mechanisms to better approach this issue, perhaps by using all the technology currently available to collect this information through apps on a national scale, as we have already seen in some isolated initiatives. In doing so, the recreational sector could perform better than the commercial sector in Brazil, for which the collection of detailed catch statistics by species and state was interrupted in 2007 (IBAMA 2007). Estimates of Brazilian marine recreational catches produced by Freire et al. (2020) could then be revisited in light of a wider information base. Finally, recreational fishers should understand the importance of acquiring the fishing license and answer all questions that are part of the license in the best possi- 
ble way, as they provide valuable information for establishing control and regulatory mechanisms. Directing funds collected with the sale of these fishing licenses to research, construction of public ramps, educational programs for fishing guides, mechanisms to register catches (landed and released), among others, would encourage recreational fishers to adhere to the licensing system.

\section{ACKNOWLEDGEMENTS}

We would like to thank all recreational fishers interviewed during this study, who also allowed us to measure their catch, and Juarez Rodrigues da Silva and Felipe Pinto Nascimento for helping with the interviews. Recreational fishers Fábio Gomes and Rodrigo Melins clarified many issues raised during the elaboration of this manuscript. This study was supported by the National Council for Scientific and Technological Development CNPq (Edital Universal \#478422/2006-7).

\section{REFERENCES}

Alves Junior UjM, Rotundo MM, Petrere Junior M, Barrella W, Ramires M. 2020. Recreational fishing on the maritime fishing pier in Mongaguá (Brazil), Southwest Atlantic. Res Soc Dev. 9 (9): e937998020.

Babali N, Kacher M, Belhabib D, LOUANChi F, PAULY D. 2018. Recreational fisheries economics between illusion and reality: the case of Algeria. PLoS ONE. 13 (8): e0201602.

Barrella W, Cachola N, Ramires M, Rotundo MM. 2016. Aspectos biológicos e socioeconômicos da pesca esportiva no "deck do pescador" de Santos (SP, Brasil). Braz J Aquat Sci Technol. 20 (1): 61-68.

BASAglia TP, VIEIRA JP. 2005. A pesca amadora recreativa de caniço na Praia do Cassino, RS: necessidade de informações ecológicas aliadas à espécie alvo. Braz J Aquat Sci Technol. 9 (1): 25-29.

Belhabib D, Campredon P, Lazar N, Sumaila UR, Baye BC, Kane EA, Pauly D. 2016. Best for pleasure, not for business: evaluating recreational marine fisheries in West Africa using unconventional sources of data. Palgrave Comm. 2 (1): 15050.

BraUn AS, FonTOURA NF. 2004. Reproductive biology of Menticirrhus littoralis in southern Brazil (Actinopterygii: Perciformes: Sciaenidae). Neotrop Ichthyol. 2 (1): 31-36.

CEPENE. 2007. Boletim estatístico da pesca marítima e estuarina do Nordeste do Brasil - 2005. Centro de Pesquisa e Gestão de Recursos Pesqueiros do Litoral Nordeste, Tamandaré, Pernambuco, Brazil. 78 p.

Coleman FC, Figueira WF, Ueland JS, CrowDER LB. 2004. The impact of United States recreational fisheries on marine fish populations. Science. 305 (5692): 1958-1960.

EsPedido JC, Parducho VA, Yap MA, PaloMARES MLD. 2014. The recreational marine sport fisheries catch of the Philippines, 19502010. In: Palomares MLD, Pauly D, editors. Philippine marine fisheries catches: a bottomup reconstruction, 1950 to 2010. Fish Centre Res Rep. 22 (1): 92-104.

[FAO] FoOd AND Agriculture ORganizATION OF THE UNITED NATIONS. 2012. Recreational fisheries. FAO Technical Guidelines for Responsible Fisheries. $N^{o}$ 13. Rome: FAO. 176 p.

[FAO] Food ANd Agriculture Organization of THE United NATIONS. 2016. The state of world fisheries and aquaculture 2016. Contributing to food security and nutrition for all. Rome: FAO. 200 p.

FÁvaro LF, Frehse FA, Oliveira RN, Schwarz JR. R. 2005. Reprodução do bagre amarelo, Cathorops spixii (Agassiz) (Siluriformes, Ariidae), da Baía de Pinheiros, região estuarina do litoral do Paraná, Brasil. Rev Bras Zool. 22 (4): 1022-1029. 
FREIRE KMF. 2010. Unregulated catches from recreational fisheries off northeastern Brazil. Atlântica. 32 (1): 87-93.

Freire KMF, Belhabib D, Espedido JC, Hood L, KLEISNER KM, LAM VWL, Machado ML, Mendonça JT, MeEuwig JJ, Moro PS, et al. 2020. Estimating global catches of marine recreational fisheries. Front Mar Sci. 7: 12.

Freire KMF, Luz RMCA, SANTOS ACG, OliveIRA CS. 2017. Analysis of the onshore competitive recreational fishery in Sergipe. B Inst Pesca. 43 (4): 487-501.

Freire KMF, Pinto Nascimento F, Rocha GRA. 2020. Shore-based competitive recreational fisheries in southern Bahia, Brazil: a baseline study. Mar Fish Sci. 33 (2): 183-203.

Freire KMF, Pauly D. 2005. Richness of common names of Brazilian marine fishes and its effect on catch statistics. J Ethnobiol. 25 (2): 279-296.

FreIRE KMF, Sumaila UR. 2019. Economic potential of the Brazilian marine recreational fishery. Bol Inst Pesca. 45 (1): e412.

Freire KMF, Tubino RA, Monteiro-Neto C, Andrade-Tubino MF, Belruss CG, TOMÁs ARG, Tutui SLS, Castro PMG, Maruyama LS, CATElla AC, et al. 2016. Brazilian recreational fisheries: current status, challenges and future direction. Fish Manage Ecol. 23: 276290.

Froese R, Pauly D. 2019. FishBase. Version 12/2019. [accessed retrieved 2019 March]. https://www.fishbase.org.

Hanazaki N, Begossi A. 2006. Catfish and mullets: the food preferences and taboos of caiçaras (southern Atlantic forest coast, Brazil). Interciencia. 31 (2): 123-129.

Henke JL, Chaves PTC. 2017. Ictiofauna e pesca amadora no litoral sul do Paraná: estudo de caso sobre capturas e potencial impacto. Braz J Aquat Sci Technol. 21 (1): 37-43.

Holder PE, JeAnson AL, Lennox RJ, BrownsCOMBe JW, Arlinghaus R, Danylchuk AJ, Bower SD, Hyder K, Hunt LM, Fenichel EP, et al. 2020. Preparing for a changing future in recreational fisheries: 100 research questions for global consideration emerging from a horizon scan. Rev Fish Biol Fisheries. 30: 137-151.

[IBAMA] Instituto Brasileiro do Meio Ambiente e dos Recursos Naturais RenoVÁveIS. 2007. Estatística da Pesca. 2007. Grandes regiões e unidades da federação. Brasília: IBAMA. 113.

Lewis DS, Braun AS, Ferreira NF. 1999. Relative seasonal fish abundance caught by recreational fishery on Cidreira Pier, southern Brazil. J Appl Ichthyol. 15: 149-151.

[MPA/MMA] Ministério dA Pesca e AquicultURA/Ministério do MEIO Ambiente. 2012. Instrução Normativa Interministerial MPA/ MMA No 09, de 13 de junho de 2012. Estabelece normas gerais para o exercício da pesca amadora em todo o território nacional. Brasília: MPA/MMA

SCHRAMM JR. HL, HARRISON JC. 2008. Competitive fishing and its role in recreational fisheries management. In: AAS O, editor. Global challenges in recreational fisheries. Oxford: Blackwell Publishing. p. 237-267. 
